\title{
ACADEMIC FREEDOM: A CHOICE BETWEEN CONSERVATIVE OR LIBERAL PERCEPTIONS - THE CASE OF THE UNITED STATES
}

\author{
Katarzyna Maćkowska*
}

\begin{abstract}
It is only the minimum extent to which the law becomes the instrument of coping with social tautness regarding the academic freedom. On the one hand, legal provisions significantly limit the number of cases related to hate crimes but on the other, they sometimes narrow a discussion due to difficulties in harmonizing individual's rights and campuses' perception - a phenomenon, which in the U.S. had been called as "chilling" the freedom. Undoubtedly, the enactment of free speech or academic freedom regulations at universities is necessary as it helps to prevent from a "hate speech" but the legal shape of this process has been strictly connected to a determination for either liberal or conservative description of the academic freedom. Regarding the newest Niche's rankings, ten universities have been selected, five out of the most liberal and five the most conservative public ones. Furthermore, two catholic universities have been added to describe differences in defining the academic freedom. Moreover, some references have been made to the U.S. Supreme Court decisions, and the very fundamental documents, namely the 1940 Statement and Harvard Free Speech Guidelines. In the separate article a problem of legislative acts that had been enacted for the past two years in a response to Report of the Committee on Freedom of Expression by the University of Chicago of 2014 will be covered. A few remarks upon this matter have been hereby made, though.
\end{abstract}

Dr. habil. Katarzyna Maćkowska Professor of KUL, Faculty of Law, Canon Law and Administration, The John Paul II Catholic University of Lublin, e-mail: kzasepa@kul.lublin.pl, ORCID: 0000-0002-1744-931X. 
The article is based on a dogmatic legal method, including quotations of legal sources and their subsequent analysis.

Keywords: academic freedom, American universities, free speech at campuses

\section{INTRODUCTION}

A major terminological problem concerns the meaning of liberal and conservative universities. To some degree a colloquial understanding of both of these attributes should apply but since this article does not evaluate which solution is proper, better or more efficient, the term "leftist" ideology has been here avoided and the current descriptions of what liberalism and conservatism are, have been omitted. Nonetheless, it must be clarified that "liberal" universities usually stress their openness towards diversity, including sex identity, gender, and same-sex marriages. In other words, they accept liberalism not in its traditional classical sense, but liberalism as identity liberalism. In the context of academic freedom, one may conclude that at liberal institutions progressive ideas predominate, while conservative universities either expressly or indirectly refer to tradition, religious beliefs, anti-liberal morality, in other words they reject morality understood as a choice of values by an autonomous individual and envision a more limited status of individuals and identity groups at the campus community. Furthermore, such ideologies may have an impact not only on academic discourse but also on the functioning of the campus as well ${ }^{1}$.

In 2015, Peter Wright in his essay published in the Harvard Political Review, wrote:

"There is an argument to be made by some students [...] that free speech should be limited in order to allow others to speak. However, this idea is flawed. If only those with more politically correct views are allowed to voice their opinions, then they would effectively discriminate against all

1 See also: Andrzej Bryk, "Wypaczona istota edukacji”, Rzeczpospolita 15.08.2019, https://www.rp.pl/Rzecz-o-prawie/308159992-Bryk-wypaczona-istota-edukacji.html. 
who held contradictory opinions. The declaration that every voice should be included, except for those less inclusive, can be viewed as hypocrisy"2.

In Poland ${ }^{3}$ academic freedom has become a significant field of study. It is only the minimum extent, however, to which the law becomes the instrument of coping with social tautness regarding free expression. On the one hand, legal provisions significantly limit the number of cases related to the so called hate crimes but on the other, they sometimes narrow a discussion due to difficulties in harmonizing individual's rights and campus rules - a phenomenon, which in the U.S. had been called as having a "chilling effect" on freedom.

Undoubtedly, the enactment of free speech or academic freedom regulations at universities is necessary as it helps to prevent "hate speech" but the idea of hate speech itself has been a subject of incessant debate both at the federal, state and campus levels. Apparently, a battle between liberal and conservative approaches sometimes allows for "hate speech" to be treated as an instrument of stifling a free inquiry. For some people, an assessment or criticism of a particular point of view is a justified opinion, but for others it may be considered as a grave offence or hate crime. Thus, careful regulation of hate crimes, commensurate with constitutional guarantees, should be applied in order that academic freedom is not limited.

2 Peter Wright, "Problematic: The Battle for Free Speech", Harvard Political Review, published December 6, 2015, http://harvardpolitics.com/harvard/problematic-battle-free-speech/.

3 Among Polish researchers in the past six years, the issue of an academic freedom has been raised by: Marcin Górski, "Standardy ochrony wolności wypowiedzi akademickiej w perspektywie porównawczej”, Państwo i Prawo 10/2019: 41-60. Jacek Sobczak, "Czy wolność słowa i wolność prasy są rzeczywiście potrzebne społeczeństwu i państwu?”, Ruch Prawniczy, Ekonomiczny i Socjologiczny 1(2018): 133.150. Zbyszko Melosik, „Uniwersytet współczesny i rekonstrukcje wolności akademickiej”, Studia Pedagogiczne L/2017: 23-36. Sylwia Jarosz-Żukowska, Łukasz Żukowski, „Wolność badań naukowych i nauczania”, in Realizacja i ochrona konstytucyjnych wolności i praw jednostki w polskim porządku prawnym, ed. Mariusz Jabłoński, Wrocław 2014, 709-740. Maria Gołda-Sobczak, "International Aspect of the Status of Academic Freedom in European Culture", Środkowoeuropejskie Studia Polityczne 3(2014): 145-168. Wojciech Brzozowski, "Konstytucyjna wolność badań naukowych i ogłaszania ich wyników”, in Prawo nauki. Zagadnienia wybrane, ed. Aleksandra Wiktorowska and Aleksander Jakubowski, Warsaw 2014: 25-45; Joanna Rezmer, Wolność badań naukowych w świetle prawa międzynarodowego, Toruń 2016. 
Interestingly, even the methodology that has been applied in this article gives an incentive for rethinking the subject itself. First of all, when seeking a proper method of selecting American universities, the rules of which should be analyzed in the context of academic freedom, the search was based on American 2020 most liberal/conservative public universities by Niche ${ }^{4}$.To a certain degree, such classification shows that one of the criteria considered by candidates is a political lean at the particular educational institution. Obviously, it would be a misrepresentation to deduce thereupon that a lack of such rankings equals to lesser interest of applicants in choosing a university due to their political and ideological views. But surveys like the abovementioned allow a preservation of global diversity parallel to local majority-homogeneity. Therefore, when academic freedom has been discussed in a context of relations between an individual (academics/student) and a campus university, this helps to balance the individual's rights and the community's expectations.

Regarding the newest Niche's rankings, ten universities have been selected, five out of the most liberal ${ }^{5}$ and the second half of the most conservative public ones ${ }^{6}$. Furthermore, two catholic universities have been added to describe differences in defining academic freedom. Moreover, some references have been made to the U.S. Supreme Court decisions, and the very fundamental documents, namely the 1940 Statement and Harvard Free Speech Guidelines. In a separate article a problem of legislative acts that have been enacted for the past two years in a response to the Report of the Committee on Freedom of Expression by the University of Chicago of 2014 is to be covered. A few remarks upon this matter have been hereby made, though.

The article is based on a dogmatic legal method, including quotations of legal sources and their subsequent analysis.

4 www.niche.com.

5 Should not be confused with the general idea of the liberal universities in the U.S. See: Julita Jabłecka, "Niezależność, autonomia i wolność akademicka a modele koordynacji szkolnictwa wyższego. Na marginesie artykułu C. Kerra”, Nauka i SzkolnictwoWyższe 1(1993): 60-61.

6 The Fashion Institute of Technology and New College of Florida excluded. 


\section{THE 1940 STATEMENT OF PRINCIPLES ON ACADEMIC FREEDOM AND TENURE AND HARVARD'S FACULTY OF ART AND SCIENCES FREE SPEECH GUIDELINES}

According to Rodney A. Smolla: "hate speech is the generic term that has come to embrace the use of speech attacks based on race, ethnicity, religion, and sexual orientation or preference" 7 . In the eternal fight between liberal and conservative views, there arises a question what are the limits of freedom of inquiry, freedom of research, and freedom of expression. When formulating the university academic freedom policy, its frame may be constructed in a twofold way. The first one pays more attention to individual's status whereas the opposite one stresses the role of the individual's responsibilities in the campus community. The merits are generally the same but application of either of them may influence the employer-employee relations when it comes to a majority-minority conflict, which, in turn, may disturb the surroundings. The famous Free Speech Guidelines of Harvard University Faculty of Arts and Sciences adopted by the Harvard Faculty of Arts and Sciences in 1990 accentuates that "the University places special emphasis, as well, upon certain values which are essential to its nature as an academic community. Among these are freedom of speech and academic freedom, freedom from personal force and violence, and freedom

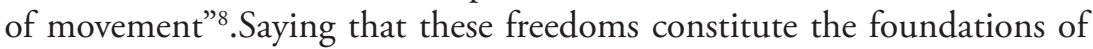
development of the academic community is a platitude, but at the same time calling out such a fundamental phrase may seem to be either vague or ambiguous when we examine how the academic freedom depends on the community, its diversity or homogeneity, conservatism or libertarianism and how individual freedoms interfere with institutional ones. Nowadays, more difficulties in finding a happy medium appear within communities with conservative, including religious majorities. Should they enjoy the institutional academic freedom in presenting views that are opposite to some values protected by the legal system? For instance, shall we accept

Rodney A. Smolla, "Academic Freedom, Hate Speech, And the Idea of A University", Law and Contemporary Problems 3(1990): 195.

8 Free Speech Guidelines of 1990, Harvard University, Faculty of Arts and Science, https:/www.fas.harvard.edu/files/fas/files/freespeech_guidelines_1990.pdf. 
that such universities conduct research questioning the anthropological and axiological validity of same-sex marriages or the right of homosexual spouses to adopt children in countries in which the legal system allows such marriages and adoptions? If we do, does this mean that positive law of the state trumps all the moral or conscience reservations of citizens who want to argue otherwise? Does it matter whether such university gets public funding or whether it is a private institution with no financial support of the government?

In the one-page Preamble of this act, it is claimed that the freedom of speech at universities is the basis for freedom of inquiry, education and rational discourse. And it clearly indicates why the freedom of speech must be protected in the academic environment. The policy also delineates what the limits of the freedom of speech are:

"There are obligations of civility and respect for others that underlie rational discourse. Racial, sexual, and intense personal harassment not only show grave disrespect for the dignity of others, but also prevent rational discourse. Behavior evidently intended to dishonor such characteristics as race, gender, ethnic group, religious belief, or sexual orientation is contrary to the pursuit of inquiry and education. Such grave disrespect for the dignity of others can be punished under existing procedures because it violates a balance of rights on which the University is based" ${ }^{\prime \prime}$.Undoubtedly, people might give the words of this clause different meanings due to their axiological assumptions, for instance religious creed.

Even more significant is the fact that these guidelines address the most critical point of discussion, namely how to solve the conflicts between existing freedoms. Obviously, there is no precise answer given as well as no explanation provided for whether one of these freedoms should be considered supreme over the others:

"It is expected that when there is a need to weigh the right of freedom of expression against other rights, the balance will be struck after a careful review of all relevant facts and will be consistent with established First Amendment standards" ${ }^{\prime 10}$.

9 Ibidem.

10 Ibidem. 
Each case requires an investigation before determining if there is any conflict between constitutional freedoms and if so, who should receive stronger protection (depending on the general legal system of the specific jurisdiction) and who should judge between them. In the U.S. this solution is pluralistic because of a federal character of the country and states' sovereignty to enact their own laws. But it must be noted that the federal Constitution remains the ultimate source of individual rights and freedoms, and, thus, there are no doubts that academic freedom of speech is protected by the First Amendment.

One of the most fundamental documents which describes academic freedom - The Statement of Principles on Academic Freedom and Tenure $^{11}$, proclaimed in 1940 by the American Association of University Professors - claims that:

"Institutions of higher education are conducted for the common good and to further the interest of either the individual teacher or the institution as a whole. The common good depends upon the free search for truth and its free exposition"12.

Furthermore, it stresses that seeking the common good is rooted in a free search for truth. This phrase requires to be looked into in the context of contemporary paradox of truth and its postmodern subjective understanding. From a general, classical view of academic freedom, which is basically perceived as truth's seeking free search for it, truth should not be limited. The antagonistic views in humanities, some relating to the core ontological and anthropological assumptions will never be equally protected by legal regulations, especially in a postmodern society when the very idea of objective truth is being questioned which makes a task of law, which should in principle facilitate the common good and social progress, even more difficult. The problem doesn't arise due to a lack of democracy but it is rooted in the need to protect it. It means that the campuses' general proclamations referring to the truth as the purpose of academic research, when a large part of the academic community questions the very concept

11 See also: Melosik, „Uniwersytet”: 23-24, “Wolność akademicka. Konteksty i rekonstrukcje”, Rocznik Lubelski 2/2013: 13-14.

12 The Statement of Principles on Academic Freedom and Tenure of 1940, https:// www.aaup.org/report/1940-statement-principles-academic-freedom-and-tenure. 
of objective truth as such, cannot solve potential conflicts let alone avoid them, for a simple reason that such conflicts reflect the modern academic culture, predominant at liberal colleges, that the aim of modern education is not a search for truth but for justice understood in the most subjective way. Assuming however that the axiological war in a liberal world is endless, the university which is based on specific values should clearly specify how to minimize hate speech, even subjectively defined.

The 1940 Statement entitles teachers to full freedom in research and in the publication of the results and to freedom of discussion in the classroom, not limited by a character of course syllabi, although the Statement encourages teachers to avoid controversies which might arise by discussing problems not related to the subject of classes. Significantly, the document explains that "controversy is at the heart of the free academic inquiry" and that "the passage serves to underscore the need for teachers to avoid persistently intruding material which has no relation to their subject"13.

On the margin of this reasoning, it goes without saying that teachers are required to respect their affiliated institution, so that when they present their personal opinions on controversial matters, they must bear in mind that their speeches may be associated with the institution. Therefore, the Statement indicates that they:

"should at all times be accurate, should exercise appropriate restraint, should show respect for the opinions of others, and should make every effort to indicate that they are not speaking for the institution"14.

This policy, the very classical understanding of academic savoir vivre ${ }^{15}$, imposes on academics the common sense rules of any civilized discussion, even if the dispute belongs to a category of controversial issues. In these days we often observe that social media supports the unrestrained voice of some academics and the problem is not that they present controversial subjects but that the manner of how they speak out is improper, that is, that they are "offensive". Due to more options we now have to present

13 Ibidem, footnote 4.

14 Ibidem, point 3.

15 See also: Andrzej Bryk, "Wykręty w służbie ideologii”, Rzeczpospolita, 10.08.2019, https://www.rp.pl/Rzecz-o-prawie/308109975-Wykrety-w-sluzbie-ideologii-Andrzej-Bryk-o-zakazie-krytyki-na-uniwersytetach-w-USA.html. 
our opinions and also to the fact that people have become more open and direct in their expressions, but first of all because western societies ceased to share the same axiological and anthropological assumptions, we must remember that criticizing in reprehensible form is different from limiting free speech. In the U.S. the law on academic freedom is related to a civility requirement.

\section{REVIEW OD JUDICIAL DEFINITIONS OF ACADEMIC FREEDOM}

The first academic freedom judicial decision of the U.S. Supreme Court $^{16}$ was decided in 1957 in re Sweezy v. New Hampshire. Academic freedom was one of the aspects determined in that case:

"The essentiality of freedom in the community of American universities is almost self-evident. No one should underestimate the vital role in a democracy that is played by those who guide and train our youth. To impose any strait jacket upon the intellectual leaders in our colleges and universities would imperil the future of our Nation. No field of education is so thoroughly comprehended by man that new discoveries cannot yet be made. Particularly is that true in the social sciences, where few, if any, principles are accepted as absolutes. Scholarship cannot flourish in an atmosphere of suspicion and distrust. Teachers and students must always remain free to inquire, to study and to evaluate, to gain new maturity and understanding; otherwise, our civilization will stagnate and die $e^{17}$.

What we must reconsider today is the western civilization's thought that academic freedom stimulates democracy. This is extremely challenging in social sciences, which when developing freely should support a common good idea. If the truth is no longer objective, academic freedom may serve a purpose of ensuring simple "diversity", understood mainly in

16 The recent publication covering the evolution of the academic freedom in the U.S. has been: Matthew J. Hertzog, Protections of Tenure and Academic Freedom in the United States. Evolution and Interpretation, Palgrave Macmillan, Cham 2017.

17 Sweezy v. New Hampshire, 354 U.S. 234 (1957), https://supreme.justia.com/cases/federal/us/354/234/ [access: 16.04.2020]. See also: Marcin Górski, "Standardy ochrony wolności wypowiedzi akademickiej w perspektywie porównawczej", Państwo i Prawo 10(2019): 50-51. 
liberal identity ideological terms. Democracy also requires an open public debate so when it comes to zero-sum game we usually end up with unsolvable tensions.

The most crucial judicial decision was Keyishian v. Board of Regents. After this case had been decided, the academic freedom gained an expressly stated protection of the First Amendment. Judge Brennan cited, among others, the opinion in re Shelton v. Tucker, in which freedom of speech, free press and freedom of assemblies were considered as the very foundation of constitutional government and thereby the academic freedom has become one of the pillars of democracy. According to the U.S. Supreme Court:

"Our Nation is deeply committed to safeguarding academic freedom, which is of transcendent value to all of us, and not merely to the teachers concerned. That freedom is therefore a special concern of the First Amendment, which does not tolerate laws that cast a pall of orthodoxy over the classroom"18.

In regard to ties between democracy, free speech and politics, it seems to be meaningful that in 1967 the protection given to the academic freedom dictated against traditional understanding of the role of an individual in community, while today those freedoms are often called out to fight for abolishing a supremacy of individualism. This observation somehow confirms that free speech will always bring social anxiety, especially in a digital era when so many people have not only a right but also a chance to publicly speak their mind. Should free speech be called "hypocrisy”, then this "hypocrisy” perfectly reflects how difficult democracy is and how much maturity it requires from its beneficiaries. To fully understand that within past years nothing else but politics has modified how we perceive the freedom of speech, including academic freedom, we should not forget the reasoning of Justice Clark who had dissented from the majority opinion in Keyishian:

"Our public educational system is the genius of our democracy. The minds of our youth are developed there and the character of that development will determine the future of our land. Indeed, our very existence depends upon it. The issue here is a very narrow one. It is not freedom

18 Keyishian v. Board of Regents, 385 U.S. 589 (1967), https://supreme.justia.com/ cases/federal/us/385/589/. See also: Górski, 51. 
of speech, freedom of thought, freedom of press, freedom of assembly, or of association, even in the Communist Party. It is simply this: may the State provide that one who, after a hearing with full judicial review, is found to have willfully and deliberately advocated, advised, or taught that our Government should be overthrown by force or violence or other unlawful means; or to have willfully and deliberately printed published, etc., any book or paper that so advocated and to have personally advocated such doctrine himself; or to have willfully and deliberately become a member of an organization that advocates such doctrine, is prima facie disqualified from teaching in its university? My answer, in keeping with all of our cases up until today, is "Yes! $!^{19}$.

Starting with communism and Marxism and utterances against the government through racism as the backgrounds for considering a meaning of academic freedom, currently a deep conflict between the traditional approach that there is one objective truth and progressive views on diversity shapes the debate on the most fundamental concepts of academic freedom. Furthermore, we also demand that academic freedom protects the employment of professors, which means that for the past ten years this challenge of individual-academic community relations has still been an unsolvable one ${ }^{20}$.

In that aspect, Adams v. University of North Carolina-Wilmington explains how multifaceted the problem remains. In 2011 the United States Court of Appeals for the Fourth Circuit decided a case, in which the Appellant Michael S. Adams alleged that he had been denied a promotion due to his conversion to Christianity and his active involvement in spreading conservative values. Importantly, the Court stated that ${ }^{21}$ :

"If a federal court is not the appropriate forum in which to review the multitude of personnel decisions that are made daily by public agencies, far less is it suited to evaluate the substance of the multitude of academic

19 Keyishian, Dissenting opinion of Justice Clark, with whom Justice Harlan, Justice Stewart and Justice White joined.

20 See the article from 2009: Robert O’Neil, “New Challenges in the United States", International Higher Education 57(2009): 4-6, DOI: https://doi.org/10.6017/ ihe.2009.57.8451.

21 Citing the following U.S. Supreme Court decisions: Bishop v. Wood and Regents of the University of Michigan v. Eving. 
decisions that are made daily by faculty members of public educational institutions - decisions that require an expert evaluation of cumulative information and [are] not readily adapted to the procedural tools of judicial or administrative decision making"22.

Subsequently, the Court has quoted the Urofsky v. Gilmore case and noted that:

"the Supreme Court has not established 'a First Amendment right of academic freedom that belongs to the professor as an individual,' but rather "to the extent the Supreme Court has constitutionalized a right of academic freedom at all, it appears to have recognized only an institutional right of self-governance in academic affairs" ${ }^{23}$.

Therefore, the case has been decided under anti-discriminatory clauses. Focusing, however, on the excluded matter from the Court's judgement, it allows to conclude that the academic freedom as an individual right of lecturers and researchers would form a fragile protection to be invoked before courts when the alleged discrimination interferes with a promotion procedure. A democratic system obliges us not to discriminate against neither a liberal professor at conservative campus, nor a conservative professor at a liberal community. But this challenge is similar to a requirement imposed on judges to determine cases impartially. We may be close to an ideal but on many occasions, it is a very hard work for individuals not to forget about it.

The other context stemming from the judicial decisions is the relationship between the individual academic as an employee and a public University as an employer. In the Adams case the Court has applied „the McVey test" which compiles U.S. Supreme Court decisions in Pickering v. Board of Education and Connick v. Myers. The test demands that the Court determines:

"(1) whether the public employee was speaking as a citizen upon a matter of public concern or as an employee about a matter of personal interest; (2) whether the employee's interest in speaking upon the matter of public concern outweighed the government's interest in providing effective and

22 Adams v. University of North Carolina-Wilmington

23 Ibidem. 
efficient services to the public; and (3) whether the employee's speech was a substantial factor in the employee's [adverse employment] decision" ${ }^{24}$.

When analyzing judicial decision in the U.S. regarding academic freedom from the Polish perspective it should be accentuated that the coming years will bring more legal disputes in consideration of academic freedom and that this embraces the following fields:

- relations between lecturer/researcher and university as employee/ employer and the private utterances of the lecturer/researcher;

- relations between lecturer/researcher and university as employee/ employer and the public utterances of the lecturer/researcher;

- relations between lecturer and students and the role of the lecturer as a person responsible for a proper communication in the classroom as well as students' arguments having little do with the content of the lecture and its objective presentation but its "offensive" character in the student's eyes.

Universities should consider whether more formalities governing this issue would either reduce or - unintentionally - increase the number of such disputes. The sooner the decision is made and the experiment carried out, the faster the problem would be "tamed” and the system prepared for the fact that the legal system will never efficiently balance the limits of academic freedom.

\section{THE ROLE OF LEGISLATIVE ACTS IN PROTECTING FREEDOM OF SPEECH - GENERAL REMARKS}

First of all, it should be noted that in the past years many states have enacted laws in order to support free speech at educational institutions. Given that there is a wide political background that determines this new legislative movement, this subject will be discussed in a separate publication. Below few words must be however added to mark the problem regarding recent documents, one, issued by the U.S. Justice Department, and the other - the Report of the Committee on Freedom of Expression

24 Ibidem. McVey V. Stacy, 157F. 3d 277-78 (1998). 
dated back to 2014, which have had a huge impact on subsequent legislation throughout the U.S.

On December 9, 2019, the U.S. Justice Department posted the Statement of Interest relating to a lawsuit filed under Mississippi law by a Jones College' student. The plaintiff claims that freedom of speech is unconstitutionally restricted by the College's internal regulations requiring that students must seek approval for meetings and gatherings at least 72 hours in advance. On the one hand, if a meeting with a controversial topic is intended, there are some safety reasons which should be considered by the universities' government, what may result in prohibiting a meeting. On the other, the number of gatherings that had been cancelled for fear of riots may be understood as a First Amendment violation. This Statement is significant because it includes a direct reference to Orwell's "1984" and it expresses that preconditions to speech "might not be out of place in Oceania, [...] the First Amendment to the United States Constitutions [...] ensures that preconditions like these have no place in the United States of America" 25 .

In 2014 the President and Provost of the University of Chicago appointed a Committee on Freedom of Expression. Briefly referring to this report, one conclusion is particularly worth quoting as sometimes it is unresolvable to balance the right of an individual university employee to raise controversial matters and the need of the university as a community for undisturbed functioning. Applying a part of the report, the priority is given to a right of an individual due to a stimulation of knowledge. Either agreeing or disagreeing therewith, a digitalized democracy demands a serious discussion and, in those countries, where such a discussion has not even started out, the American experience would be extremely significant.

Speaking of the report, the Committee says:

"[...] It is for the individual members of the university community, not for the University as an institution, to make those judgment for themselves, and to act on those judgments not by seeking to suppress speech, but by openly and vigorously contesting the ideas that they oppose. Indeed, fostering the ability of members of the University community to

25 https://www.justice.gov/opa/pr/justice-department-files-statement-interest-supporting-campus-free-speech. 
engage in such debate and deliberation in an effective and responsible manner is an essential part of the University's educational mission"26.

\section{UNIVERSITY RULES - SELECTED EXAMPLES}

With the methodology explained in the introduction, a classification of academic freedom/freedom of expression definitions have been hereby presented. The starting point is a consent that liberal and conservative views should be freely spoken out at the campuses by both professors and students. The question whether the political lean of the campus should impact the individuals-campuses relations, would - at this point - remain unanswered and as such it requires further academic discussion, especially from the Polish perspective. But the analysis of the internal rules of the selected universities allows for a formulation of a thesis that the liberal universities adapt various description of academic freedom, while the conservative universities implement more homogeneous responsibility-based definitions. Catholic and in general Christian campuses represent a separate category because they expressly indicate which Christian values must be respected, although they can be defined in a conservative, orthodox way, or progressive liberal way which makes a crucial difference. It goes without saying that final thesis requires a more detailed and complex survey.

\subsection{Conservative universities}

Utah State University has enacted a faculty-dedicated policy regarding academic freedom - a relatively long and detailed document. The last revision is dated back to 2012. This university in its policy stresses that:

"Thought and understanding flourish only in a climate of academic freedom and integrity, expressed collectively by colleges and departments as well as individually through research and teaching and as they exist within the wider context of advanced study as commonly understood by all universities. The community also values diversity and respect, without which there can be no collegiality among faculty and students. In addition,

26 Report of the Committee of Freedom of Expression. 
the university community values individual rights and freedoms, including the right of each community member to adhere to individual systems of conscience, religion, and ethics. Finally, the university recognizes that with all rights come responsibilities" 27 .

Interestingly, to say that each has an individual system of ethics makes any sensible discussion of morality of freedom of speech meaningless. In addition to emphasizing the responsibilities, the policy also states that:

"The university itself shall not violate the academic freedom of any faculty member or the freedom of any student to learn and shall use its powers and resources to defend its faculty and students from unjustified attempts to compromise or restrict those freedoms, even should the exercise of those freedoms generate hostility" 28 .

The Angelo State University, located in Texas, claims its strong commitment to:

"the principles of academic freedom for faculty in teaching, research, and the publication of scholarly inquiry accompanied by an equally demanding concept of responsibility" 29 .

Judiciousness in introducing controversial matter in the classroom is demanded from the faculty, including a requirement that controversies must remain in relation to a class topic. Moreover, freedom in research must be accompanied by „responsible academic and professional practices" ${ }^{\prime \prime}$.

As we can see, this policy is directly derived from the 1940 Statement of Principles on Academic Freedom. In 2012 The Faculty of the Senate of the University of Tennessee requested:

"that the University of Tennessee Board of Trustees expand the definition of academic freedom to include protection for shared governance and other employment-related speech" 31 .

27 Policy Manual No. 403, Section 1, https://www.usu.edu/policies/403/.

28 Ibidem, Section 2.1.

29 Operating Policy and Procedure 04.04, https:/www.angelo.edu/content/ files/14136-op-0404-academic-freedom.

30 Ibidem, Section 1.

31 The Faculty Senate of the University of Tennessee-Knoxville Resolution, http:// senate.utk.edu/wp-content/uploads/sites/16/2011/09/2-Academic-Freedom-resolution-for-board-action.pdf. 
In the policy of the Board of Trustees, additionally to the exclusion of controversies not related to the course subject, a cautiousness in expressing personal views is also recommended. Generally, the policy, partially rooted in the 1940 Statement points out:

"A healthy tradition of academic freedom and tenure is essential to the proper functioning of a University. At the same time, membership in a society of scholars enjoins upon a faculty member, certain obligations to colleagues, to the University and to the State that guarantees academic freedom. [...] The primary responsibility of a faculty member is to use the freedom of his or her office in an honest, courageous, and persistent effort to search out and communicate the truth that lies in the area of his or her competence. [...] A faculty member is entitled to full freedom in research and in publication of the results, subject to the adequate performance of his or her other academic duties [...]. A faculty member should recognize that the right of academic freedom is enjoyed by all members of the academic community. He or she should be prepared at all times to support actively the right of the individual to freedom of research and communication as defined herein" 32 .

Under the Statutes of the University of North Georgia:

„University Faculty members are entitled to full freedom of expression in research, teaching, and publishing, subject only to those restrictions that are imposed by professional ethics and respect for the rights of others. University Faculty members have the right to criticize and seek alteration of both academic and non-academic University policies, whether or not those policies affect them directly. University Faculty are free from institutional censorship, discipline, or reprisal affecting their professional careers for exercising freedom of expression ${ }^{33}$.

It also quotes the 1940 Statement in the Faculty Handbook ${ }^{34}$.

As of April 2020, the University of Mississippi has no directly addressed policy governing academic freedom. On December 5, 2018 the

32 Policies Governing Academic Freedom Responsibility and Tenure, https://policy. tennessee.edu/wp-content/uploads/policytech/system-wide/bt/BT0006-Policies-Governing-Academic-Freedom-Responsibility-and-Tenure.pdf.

33 Statutes, Section 5, https://provost.uga.edu/policies/statutes/.

34 Faculty Handbook, Section 6, https://ung.edu/academic-affairs/faculty-handbook/6-academic-freedom/index.php. 
Faculty Senate enacted a resolution, in which the faculties manifested their fear of "chilling” academic freedom due to the activity of the university's chancellor. Therefore, the resolution reaffirmed an endorsement of the 1940 Statement and stated that:

„the necessity of academic freedom to the University's mission, upholds the 1940 "Statement of Principles," and encourages senior leadership to use their positions of authority judiciously, to generally refrain from questioning the credibility of faculty scholarship, and to recognize and mitigate against any and all threats to academic freedom ${ }^{35}$ ".

Currently, in the age of a polarized society, there is a danger of misusing personnel policies by both liberal and conservative universities against a campus member with opposite views. It is an endless problem of considering the academic freedom also as an extra-constitutional privilege ${ }^{36}$.

Even though the voice for protecting academics from unjustified actions taken by the university - regarding tenure and promotion - has stimulated the recent changes to the internal rules of the abovementioned universities, still it is clear that those universities describe the academic freedom in the wide context of responsibilities imposed on individuals.

\subsection{Liberal universities}

On April 1, 2015 the Academic Council of the University of California, of which two universities, Berkeley and Santa Cruz are among top liberal universities, endorsed the position of the University Committee on Academic Freedom, which in few sentences expresses support "for the tenet that UC campuses should aspire to civil discourse, so long as this tenet is not allowed to operate in practice as a restraint on academic freedom ${ }^{37}$ ".

35 Faculty Senate Resolution, https://olemiss.edu/faculty_senate/archives/Resolution-AcademicFreedom.pdf.

36 Term used and problem discussed by Ernest van den Haag, „Academic Freedom in the United States", Law and Contemporary Problems Summer 1963: 515. See also: "Academic Freedom and Tenure", Pace Law Review 5(1994), 5-13, https://digitalcommons. pace.edu/cgi/viewcontent.cgi?article=1354\&context=plr.

37 UC Academic Council Position on Academic Freedom and Civility, https://academic-senate.berkeley.edu/sites/default/files/academic_freedom_statement_endorsed_by_ council.pdf. 
The position explains that:

"academic freedom includes the right of members of the university community to express their views, even in passionate terms, on matters of public importance ${ }^{38}$ ".

According to the Academic Personnel Manual:

"Members of the faculty are entitled as University employees to the full protections of the Constitution of the United States and of the Constitution of the State of California. These protections are in addition to whatever rights, privileges, and responsibilities attach to the academic freedom of university faculty" 39 .

At Portland State University, academic freedom is considered as the most important privilege of Faculty members but it must be enjoyed consistently with the responsibilities imposed on academics as teachers, scholars, colleagues, members of the University, administrators, and member of the non-academic community. Consequently, the faculty member should "respect and defend the free inquiry of his associates", "show due respect for the opinion of others" and "observe the stated regulations of the University, provided they do not contravene academic freedom" 40 .

The University of Oregon has indicated four contexts of academic freedom: scholarship, teaching, policy and shared governance and finally public service. Accordingly, faculty members are granted "autonomous freedom to conduct research [...] limited only by the standards and methods of accountability established by their profession $[\ldots]^{41}$ ". As teachers they have a right to "investigate and discuss matters, including those that are controversial, inside and outside of class, without fear of institutional restraint. Matters brought up in class should be related to the subject of courses or otherwise be educationally relevant $[\ldots]^{42}$ ". One may add that

38 Ibidem.

39 Academic Personnel Manual-010, https://www.ucop.edu/academic-personnel-programs/academic-personnel-policy/index.html.

40 Faculty Conduct Code, 577-041-0005, https:/www.pdx.edu/dos/psu-faculty-code-conduct\#1.

${ }^{41}$ UO Policy Statement on Academic Freedom, Section 1(a), https://policies.uoregon.edu/content/academic-freedom- 0 .

42 Ibidem, Section 1(b). 
the last postulate is, especially in the humanities, very difficult to verify and may be subject to abuse.

Moreover, they have the freedom of expressing criticism against institutional policy ${ }^{43}$ and to participate in public debate ${ }^{44}$.

Similarly, the University of San Francisco describes academic freedom in three fields: teaching and instruction, research and creative expression, as well as university governance and public expression. Faculty members are free to:

- present in both formal and informal ways the academic subject, including controversies, insofar as they refer to the course's topic ${ }^{45}$;

- "pursue any avenue of research or creative expression without interference" ${ }^{\text {" }}$;

- express their views on University governance and functioning and on matters of public concern ${ }^{47}$.

The selected liberal universities have expanded the meaning of academic freedom in all of its dimensions. They do not entail cautiousness in teaching controversies and allow informal educational methods. In addition to that, a faculty member's freedom to express opinions relating to public issues has not been impeded. In that sense, those examples give priority to a protection of individual rather than academic community.

\subsection{Catholic campuses}

What recently has been claimed by conservative academics and students is that they have no freedom to express their opinions because of liberal political correctness. One has also to bear in mind that today nominally Catholic universities may uphold the orthodox Catholic creed or may contest it accepting its liberal, progressive interpretation, which makes a difference in the context of academic freedom. It has to be remembered that freedom of speech must also be balanced with the freedom of religion

43 Ibidem, Section $1(\mathrm{c})$.

44 Ibidem, Section 1(d).

45 Academic Senate Policy on Academic Freedom Principles, \#F13-267, Section 2, https://senate.sfsu.edu/sites/default/files/\%23F13-267001.pdf.

46 Ibidem, Section 3.

47 Ibidem, Section 4. 
principle, given that both of them are different conceptual and axiological categories.

In this article the academic policies of the Catholic University of America and John Paul the Great Catholic University will be looked at. Importantly, both of these universities benefit from federal grants, what obliges them to apply current federal laws on campuses, which might conflict with their creedal mission ${ }^{48}$.

At the Catholic University of America ${ }^{49}$, pursuing truth and academic freedom in research and teaching is considered to be the very heart of the university policy, which expressly states that free speech is constitutionally protected from governmental restrictions. Without any doubt, this may imply that the campus community would support its member from any discriminatory action taken by the government. But in consideration of the object of the university, academic freedom may be limited in the context of relations between employer and employee. In its poli$\mathrm{cy}$, the university indicates that freedom to express oneself "may be constrained in a private university by other values which are held to be equal, greater or prior" ${ }^{\text {" }}$. Furthermore, the university points out that "as a private institution, is not required to provide a forum for advocates whose values are counter to those of the University or the Roman Catholic Church" and the reasons underlying these restrictions are as following:

"The University recognizes a distinction between objective explanation and advocacy in the presentation of issues. This means, therefore, that it

48 In the U.S. law it is claimed, that the source of academic freedom at private campuses lies with the University rules because the First Amendment does not apply directly. See: Rachel Levinson, Academic Freedom and the First Amendment, American Association of University Professors Summer Institute, July 2007, 18, https:/www.aaup.org/NR/ rdonlyres/57BFFE5E-900F-4A2A-B399-033ECE9ECB34/0/AcademicfreedomandFirstAmenoutline0907doc.pdf

49 On the role of catholic campuses and academic freedom see: Joseph Koterski, “Taking a Catholic View on American Freedom”, July 20, 2017, https://newmansociety.org/taking-catholic-view-academic-freedom/. Charles E. Curran, "Academic Freedom: the Catholic University and Catholic Theology", The Furrow 12(1979): 739-754.

50 Policy for Presentations and Balanced Programs, https://policies.catholic.edu/students/studentlife/organizations/presentations.html. 
may refuse permission to prospective speakers who in its judgment promote or advocate such counter values" ${ }^{51}$.

Importantly, this provision allows the University not to host a speaker who expresses opinions against catholic values. The question arises whether academic freedom is violated and freedom of speech infringed by this limitation. Undoubtedly, a catholic community has a right to conduct research and to present opinions consistent with Roman Catholic Church doctrines. Does it mean however, that opposite views should not be expressed at campus at all? The policy says that:

"balanced programs explaining positions on both sides of a controversial, societal, political, moral, and/or ecclesiastical issues may be staged in the pursuit of a more complete educational experience and a greater understanding of the issues. Hence, in such matters, even in those in which the Roman Catholic Church has expressed clear and unambiguous official teaching, programs involving knowledgeable spokespersons representing opposing viewpoints may be considered to be appropriate within the University setting" $" 52$.

This policy allows to conduct research and make speeches that include contends not consistent with the Roman Catholic Church doctrine. But there is one condition, namely the educational experience should be developed as a result of such disputes. Therefore:

"programs designed to promote action rather than understanding, while not necessarily inappropriate in themselves, are not clearly 'educational' in a strict sense" 53 .

As a result, catholic values have been protected and opposite opinions are allowed at the university forum but only to the extent that agitation does not take place. The better understanding itself has been fully protected by academic freedom.

Individual and institutional academic freedoms are heavily regulated in the John Paul the Great Catholic University's internal rules. According to its Statement:

51 Ibidem.

52 Ibidem.

53 Ibidem. 
"JP Catholic embraces the traditional freedoms of scholarship, inquiry, and dialog, together with the responsibilities implicit in its Catholic mission" 54 .

Similar to the CUA's policy, intellectual challenges and development of knowledge have been underlined as determinants for research and highly qualified teaching.

Interestingly, some institutional restrictions exist and have an impact on the university community ordinary life:

"Catholic faculty must live lives reflecting faithfulness to the Word of God and sign a statement reflecting the fidelity. [...] Faculty of other faiths must agree to respect the Catholic nature of the university and its mission, while the university in turn respects their religious convictions. [...] It is not expected that the faculty will agree on every point of Catholic doctrine, much less on the issues in the academic disciplines that commonly divide faculties everywhere. It is expected, however, that a spirit of Christian charity will unite even those with wide differences and that questions will be raised in ways that seek to strengthen rather than undermine faith" 55 .

Individual freedom is, in turn, characterized by a quotation from Pope Benedict XVI to Catholic Educators and it requires academics to seek the truth, which should be determined in its essence by a careful analysis of evidence. In addition to formal requirements, which had been addressed to the academics of JP Catholic, there is one more phrase in the Statement worth citing. The Preamble and the Conclusion include that:

"For those who seeks the truth Christ reveals, JP Catholic offers a genuinely true academic freedom" 56 .

It expressly means that JP Catholic as a private college limits academic freedom due to affirmation and promotion of Christian anthropology and the values built on it. Obviously, there is space for a dispute but only within the contours of the Catholic mission. JP Catholic understands that there is always a tension between individual and institutional academic freedom. Therefore, some solutions have been implemented in order to mitigate potential conflicts. First of all, the Statement relies on a pre-

\footnotetext{
54 Academic Freedom Statement, https://jpcatholic.edu/academics/freedom.php.

55 Ibidem.

56 Ibidem.
} 
sumption of innocence and an explanation thereof that the awareness of the person that he/she violated the standard is required. The Statement gives a few examples of such violation, mainly: public dispute or opposing fundamental Catholic teaching, intentional attack or mock the Catholic church or its hierarchy or clergy and breach of JP Catholic's Honor Code. The Summary of Statement also refers to general descriptions of violations. It stresses that neither the individual faculty freedom nor the institutional freedom should be restrained unless it involves "matters that obstruct or betray the university's identity and mission or the Catholic Church" 57.

If the private university is established in order to promote truth seeking and to protect specific values, it is entitled to restrain some activities of faculty members. This restraint, however does not have to be necessarily considered as a restriction by the faculty itself. As a practical matter, the academics at such universities usually share the same values, and, thus, such a community, though less diverse, should not be a priori claimed to abate academic freedom.

\section{FINAL CONSENSUAL CONLUSION}

Undoubtedly, the university campus, including the employer-employee relationship, must be free from harassment, discrimination, and retaliation. But the review of doctrine over recent years illustrates that discussions on academic freedom have no longer been a dispute about the universal idea of this freedom. These days, it relates more to an interdependence between both individual's and the university's right to academic freedom. This perspective has been notably connected to the dichotomy between "conservative" and "liberal" views on the role of an individual in the society. Some of the universities express the freedom in a very wide context of responsibilities, while other focus on individual' role in shaping the academic climate for developing knowledge and pursuing a truth. Globally, in western civilization, with the number of inclusively heterogeneous and different homogeneous campuses, various paths have been

57 Ibidem. 
chosen on a way to develop academic inquiries and research, as well as the educational methods.

\section{REFERENCES}

Brzozowski, Wojciech. "Konstytucyjna wolność badań naukowych i ogłaszania ich wyników”. In Prawo nauki. Zagadnienia wybrane, edited by Aleksandra Wiktorowska and Aleksander Jakubowski. Warsaw 2014: 25-45.

Curran, Charles E. "Academic Freedom: the Catholic University and Catholic Theology". The Furrow 12(1979): 739-754.

Gołda-Sobczak, Maria. "International Aspect of the Status of Academic Freedom in European Culture". Srodkowoeuropejskie Studia Polityczne 3(2014): $145-168$.

Górski, Marcin. "Standardy ochrony wolności wypowiedzi akademickiej w perspektywie porównawczej”. Państwo i Prawo 10/2019: 41-60.

Hertzog, Matthew J., Protections of Tenure and Academic Freedom in the United States. Evolution and Interpretation, Palgrave Macmillan, Cham 2017.

Jabłecka Julita. "Niezależność, autonomia i wolność akademicka a modele koordynacji szkolnictwa wyższego. Na marginesie artykułu C. Kerra". Nauka i Szkolnictwo Wyższe 1(1993): 60-61.

Jarosz-Żukowska, Sylwia, Żukowski Łukasz. "Wolność badań naukowych i nauczania”. In Realizacja i ochrona konstytucyjnych wolności i praw jednostki w polskim porządku prawnym, edited by Mariusz Jabłoński, Wrocław 2014, 709-740.

Koterski, Joseph. "Taking a Catholic View on American Freedom”. July 20, 2017, https://newmansociety.org/taking-catholic-view-academic-freedom/.

Levinson, Rachel. Academic Freedom and the First Amendment, American Association of University Professors Summer Institute. July 2007, 18, https://www. aaup.org/NR/rdonlyres/57BFFE5E-900F-4A2A-B399-033ECE9ECB34/0/ AcademicfreedomandFirstAmenoutline0907doc.pdf.

Melosik, Zbyszko, „Uniwersytet współczesny i rekonstrukcje wolności akademickiej”. Studia Pedagogiczne L/2017: 23-36.

Melosik, Zbyszko. "Wolność akademicka. Konteksty i rekonstrukcje”. Rocznik Lubelski 2/2013: 13-26.

O’Neil, Robert. "New Challenges in the United States". International Higher Education 57(2009): 4-6, DOI: https://doi.org/10.6017/ihe.2009.57.8451. 
Rezmer, Joanna. Wolność badań naukowych w świetle prawa międzynarodowego. Toruń 2016.

Smolla, Rodney A. "Academic Freedom, Hate Speech, And the Idea of A University". Law and Contemporary Problems 3(1990): 195-225.

Sobczak, Jacek. "Czy wolność słowa i wolność prasy są rzeczywiście potrzebne społeczeństwu i państwu?”. Ruch Prawniczy, Ekonomiczny i Socjologiczny 1(2018): 133.150.

Van den Haag, Ernest. "Academic Freedom and Tenure". Pace Law Review 5(1994): 5-13. https://digitalcommons.pace.edu/cgi/viewcontent.cgi?article $=1354 \&$ context $=$ plr.

Van den Haag, Ernest. "Academic Freedom in the United States", Law and Contemporary Problems Summer 1963: 515-524.

Wright, Peter. "Problematic: The Battle for Free Speech", Harvard Political Review, published December 6, 2015, http://harvardpolitics.com/harvard/problematic-battle-free-speech/. 